\title{
A New Isopimarane Diterpenoid from Vellozia pusilla Pohl (Velloziaceae)
}

\author{
Ana Letícia A. Dantas, Ligia Maria M. Valente* and Angelo C. Pinto \\ Instituto de Química, Universidade Federal do Rio de Janeiro, Centro de Tecnologia, Bloco A, 21949-270 \\ Rio de Janeiro-RJ, Brazil
}

\begin{abstract}
Um novo diterpenóide com esqueleto isopimarano, 8(9),15-isopimarandien-7-ona-20,12carbolactona (1), foi isolado da espécie Vellozia pusilla Pohl. A elucidação estrutural desta substância baseou-se em dados de UV, IV, EM, RMN ${ }^{1} \mathrm{H}$ e ${ }^{13} \mathrm{C}$ uni e bidimensional e comparação com dados de substâncias modelos.
\end{abstract}

A new isopimarane diterpenoid, 8(9),15-isopimaradien-7-one-20,12-carbolactone (1), was isolated from Vellozia pusilla Pohl. Its structure was established on the basis of UV, IR, MS, uni and bidimensional ${ }^{1} \mathrm{H}$ and ${ }^{13} \mathrm{C} \mathrm{NMR}$ and comparison of the data with model compounds.

Keywords: Vellozia pusilla, Velloziaceae, isopimarane diterpenoid

\section{Introduction}

The Velloziaceae is a family of tropical plants occurring in South America and Africa. The Brazilian species occur in the subtropical regions, especially in the states of Minas Gerais, Bahia, Goiás, Mato Grosso, Rio de Janeiro and Santa Catarina. These plants grow in a characteristic ecosystem fully exposed on mountainsides in rocky or sandy soils. Plants of the family Velloziaceae in spite of living under conditions of high solar irradiation and low water availability show surprising longevity. ${ }^{1}$

Previous studies on the species Vellozia pusilla Pohl have afforded several terpenoids, including isopimarane nor-diterpenoid and diterpenoids, cleistanthane diterpenoids and the triterpenoid lupenone. ${ }^{2-4}$

In a study of the antitumoral activity of some species of Velloziaceae, ${ }^{5}$ the methanol extract of Vellozia pusilla Pohl, colected in 1978, has shown a significant activity. Based on these results, another collection was carried out in 1993 and the new methanol extract presented about the same bioactivity and further studies are under development.

This paper reports the isolation and structural determination of a new isopimarane diterpenoid from the hexane extract of the stems, roots and leaves of Vellozia pusilla Pohl collected in Serra do Cipó (Minas Gerais Brazil) in 1993. The structure elucidation of the isolated

* e-mail: valente@iq.ufrj.br compound was performed by spectrometric analysis also involving comparison with literature data.

\section{Results and Discussion}

Compound 1 showed a molecular formula of $\mathrm{C}_{20} \mathrm{H}_{26} \mathrm{O}_{3}$ by HRFABMS ([M+H $]^{+} m / z$ 315.1969). Its ${ }^{1} \mathrm{H}$ and ${ }^{13} \mathrm{C} \mathrm{NMR}$ spectra indicated three methyl groups $\left[\left(\delta_{\mathrm{H}} 1.00 \mathrm{~s}, 3 \mathrm{H}, \delta_{\mathrm{C}}\right.\right.$ $\left.21.3) ;\left(\delta_{\mathrm{H}} 1.15 \mathrm{~s}, 3 \mathrm{H}, \delta_{\mathrm{C}} 29.8\right) ;\left(\delta_{\mathrm{H}} 1.23 \mathrm{~s}, 3 \mathrm{H}, \delta_{\mathrm{C}} 32.4\right)\right]$, a vinyl group attached to a quaternary carbon $\left[\delta_{\mathrm{H}} 4.92 \mathrm{~d}(J\right.$ $17.5 \mathrm{~Hz}) ; \delta_{\mathrm{H}} 5.00 \mathrm{~d}(J 10.8 \mathrm{~Hz}), \delta_{\mathrm{H}} 5.67 \mathrm{dd}(J 17.5$ and 10.8 $\mathrm{Hz})$ and $\delta_{\mathrm{C}} 113.1\left(\mathrm{CH}_{2}\right)$ and $\left.\delta_{\mathrm{C}} 142.5(\mathrm{CH})\right]$, an oxygenated methine carbon $\left[\delta_{\mathrm{H}} 5.08\right.$ dddd $(J 8.9,7.0,2.0$ and $2.0 \mathrm{~Hz})$, $\delta_{\mathrm{C}}$ 74.0], two tetrasubstituted $\mathrm{sp}^{2}$ carbons $\left(\delta_{\mathrm{C}} 131.5\right.$ and $153.3)$, an ester carbonyl $\left(\delta_{\mathrm{C}} 171.5\right)$ and a ketone carbonyl $\left(\delta_{\mathrm{C}}\right.$ 198.7) (Table 1$)$.

These data along with the knowledge of the presence of isopimarane diterpenoids in this plant species ${ }^{2,4}$ suggested the presence of an isopimarane carbon skeleton in $\mathbf{1}$.

The IR and UV absorption bands $\left(v 1683 \mathrm{~cm}^{-1}\right.$ and $\lambda_{\max } / \mathrm{nm} 254(\mathrm{MeOH})\left(\varepsilon / \mathrm{dm}^{3} \mathrm{~mol}^{-1} \mathrm{~cm}^{-1} 19.9 \times 10^{3}\right)$ showed the presence of an $\alpha, \beta$ - unsaturated ketone carbonyl. The chemical shifts $\delta_{\mathrm{C}} 131,5$ and 153,3 indicated that C-C double bond was conjugated with this ketone carbonyl.

The absence of the fourth methyl group as expected for isopimarane carbon skeleton compounds, showed by the ${ }^{1} \mathrm{H}$ and ${ }^{13} \mathrm{C}$ NMR spectra data of compound $\mathbf{1}$ together with the complete NMR spectral analysis including COSY, HMQC and HMBC spectral correlations (Figure 1) and the comparison of its ${ }^{13} \mathrm{C}$ NMR data with those of the M1, 
Table 1. ${ }^{1} \mathrm{H}$ and ${ }^{13} \mathrm{C}(300 \mathrm{MHz}) \mathrm{NMR}$ spectral data of compound (1) in $\mathrm{CDCl}_{3}{ }^{\mathrm{a}}$

\begin{tabular}{|c|c|c|c|c|}
\hline \multirow[b]{2}{*}{$\# \mathrm{C}$} & \multirow[b]{2}{*}{$\delta{ }^{13} \mathrm{C}$} & \multirow[b]{2}{*}{$\delta{ }^{1} \mathrm{H}$ (mult., $\left.J(\mathrm{~Hz})\right)$} & \multicolumn{2}{|c|}{ НMBC } \\
\hline & & & ${ }^{2} J_{\mathrm{CH}}$ & ${ }^{3} J_{\mathrm{CH}}$ \\
\hline 1 & $34.8\left(\mathrm{CH}_{2}\right)$ & $1.35-1.50(\mathrm{~m}) ; 2.15-2.35(\mathrm{~m})$ & & \\
\hline 2 & $18.7\left(\mathrm{CH}_{2}\right)$ & $1.50-1.70(\mathrm{~m}) ; 1.70-1.85(\mathrm{~m})$ & & \\
\hline 3 & $40.6\left(\mathrm{CH}_{2}^{2}\right)$ & $1.20-1.35(\mathrm{~m}) ; 1.50-1.70(\mathrm{~m})$ & & $3 \mathrm{H}-18,3 \mathrm{H}-19$ \\
\hline 4 & $32.1(\mathrm{C})$ & - & H-5, 3H-18, 3Н-19 & \\
\hline 5 & $45.1(\mathrm{CH})$ & $1.98(\mathrm{bd}, J 15.0)$ & & $3 \mathrm{H}-18,3 \mathrm{H}-19$ \\
\hline 6 & $36.7\left(\mathrm{CH}_{2}\right)$ & $2.50(\mathrm{dd}, J 15.0$ and 2.0$) ; 2.15(\mathrm{t}, J 15.0)$ & $\mathrm{H}-5$ & \\
\hline 7 & $198.7(\mathrm{C})^{2}$ & - & $2 \mathrm{H}-6$ & $\mathrm{H}-5$ \\
\hline 8 & $131.5(\mathrm{C})$ & - & $2 \mathrm{H}-14$ & \\
\hline 9 & $153.3(\mathrm{C})$ & - & $2 \mathrm{H}-11$ & $2 \mathrm{H}-14$ \\
\hline 10 & $49.5(\mathrm{C})$ & - & $\mathrm{H}-5$ & \\
\hline 11 & $38.1\left(\mathrm{CH}_{2}\right)$ & $1.25(\mathrm{~d}, J 2.0) ; 2.25-2.35(\mathrm{~m})$ & & \\
\hline 12 & $74.0(\mathrm{CH})$ & $5.08(\mathrm{dddd}, J 8.9,7.0,2.0$ and 2.0$)$ & $2 \mathrm{H}-11$ & $3 \mathrm{H}-17$ \\
\hline 13 & $35.5(\mathrm{C})$ & - & $\mathrm{H}-14, \mathrm{H}-12,3 \mathrm{H}-17$ & \\
\hline 14 & $33.7\left(\mathrm{CH}_{2}\right)$ & $2.0(\mathrm{bd}, J 15.3) ; 2.6(\mathrm{bd}, J 15.3)$ & & $3 \mathrm{H}-17$ \\
\hline 15 & $142.5(\mathrm{CH})$ & $5.67(\mathrm{dd}, J 17.5$ and 10.8$)$ & $3 \mathrm{H}-17$ & \\
\hline 16 & $113.1\left(\mathrm{CH}_{2}\right)$ & $4.92(\mathrm{~d}, J 17.5) ; 5.00(\mathrm{~d}, J 10.8)$ & & \\
\hline 17 & $29.8\left(\mathrm{CH}_{3}\right)$ & $1.14(\mathrm{~s})$ & & \\
\hline 18 & $32.4\left(\mathrm{CH}_{3}\right)$ & $1.00(\mathrm{~s})$ & & \\
\hline 19 & $21.3\left(\mathrm{CH}_{3}\right)$ & $1.23(\mathrm{~s})$ & $3 \mathrm{H}-18$ & \\
\hline 20 & $171.5(\mathrm{C})$ & - & & \\
\hline
\end{tabular}

${ }^{a}$ Chemical shifts $\left(\delta{ }^{1} \mathrm{H}\right.$ and $\left.\delta{ }^{13} \mathrm{C}\right)$, coupling constants $(J)$ and multiplicity of signals obtained from the correlations of one dimensional ${ }^{1} \mathrm{H}$ and ${ }^{13} \mathrm{C}$ NMR spectra, homonuclear ${ }^{1} \mathrm{H}-{ }^{1} \mathrm{H}$ COSY and heteronuclear ${ }^{1} \mathrm{H}_{-13}{ }^{13} \mathrm{C} \mathrm{HMQC}$ spectra. ${ }^{1} \mathrm{H}-{ }^{13} \mathrm{C}$ HMBC ${ }^{n} J_{\mathrm{CH}}(\mathrm{n}=2$ and 3) spectra were also used for these assignments.

M2 and M3 model compounds ${ }^{2,6,7}$ (Figure 2) showed the presence of a $\gamma$-lactone at the C-20/C-12 in $\mathbf{1}$.

This was confirmed by the multiplicity of the oxygenated methine proton in the ${ }^{1} \mathrm{H}$ NMR spectra $\left[\delta_{\mathrm{H}}\right.$ 5.08 dddd $(J 8.9,7.0,2.0$ and $2.0 \mathrm{~Hz})$ ], which showed the coupling with four other hydrogens and by the downfield shift of the ${ }^{13} \mathrm{C}$ NMR signal of the C-10 ( 10 ppm), caused by the $\beta$ deshielding effect from the $\mathrm{C}-20$ lactone carbonyl. The HRCG-EIMS of compound $\mathbf{1}$ showed no $\mathrm{M}^{+}$and peaks at $\mathrm{m} / z 270$ and 286 suggesting loss of $\mathrm{CO}_{2}$ and $\mathrm{CO}$ respectively.

The stereochemistry at C-13 was established by comparison of the ${ }^{13} \mathrm{C}$ NMR chemical shifts of C-15, C-16 and $\mathrm{C}-17$ with those of isopimarane diterpenoids, ${ }^{6,8}$ showing a $\beta$-equatorial position for the $\mathrm{C}$ - 17 methyl group and an $\alpha$ axial position for the vinyl group. Comparison of the optical rotation value of $1\left\{[\alpha]_{\mathrm{D}}+41.7^{\circ}\left(\mathrm{CHCl}_{3}\right)\right\}$ with that of the

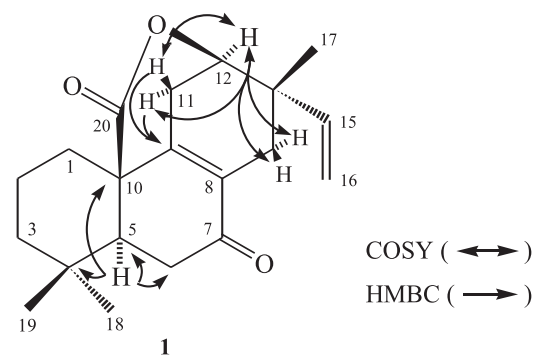

Figure 1. The structure of compound 1 with its selected ${ }^{1} \mathrm{H}_{-}{ }^{13} \mathrm{C}$ $\mathrm{HMBC}$ and ${ }^{1} \mathrm{H}-{ }^{1} \mathrm{H}$ COSY correlations. model compound M4 $4^{9}$ also isolated from V. pusilla ${ }^{2}$ (Figure 2) $\left\{[\alpha]_{\mathrm{D}}+26.3^{\circ}\left(\mathrm{CHCl}_{3}\right)\right\}$ and considering the stereochemistry of the $\mathrm{A} / \mathrm{B}$ ring junction of the isopimarane diterpenoids hitherto isolated from Velloziaceae ${ }^{6}$ compound $\mathbf{1}$ was regarded as a normal-diterpenoid. The observation of the coupling constants for $\mathrm{H}-12$ in $\mathbf{1}\left[\delta_{\mathrm{H}} 5.08\right.$ dddd $(J 8.9,7.0$, 2.0 and $2.0 \mathrm{~Hz}$ )] showed it to be an equatorial hydrogen and consequently $\alpha$-orientated. Thus, from the foregoing evidence, the relative configuration of compound $\mathbf{1}$ was
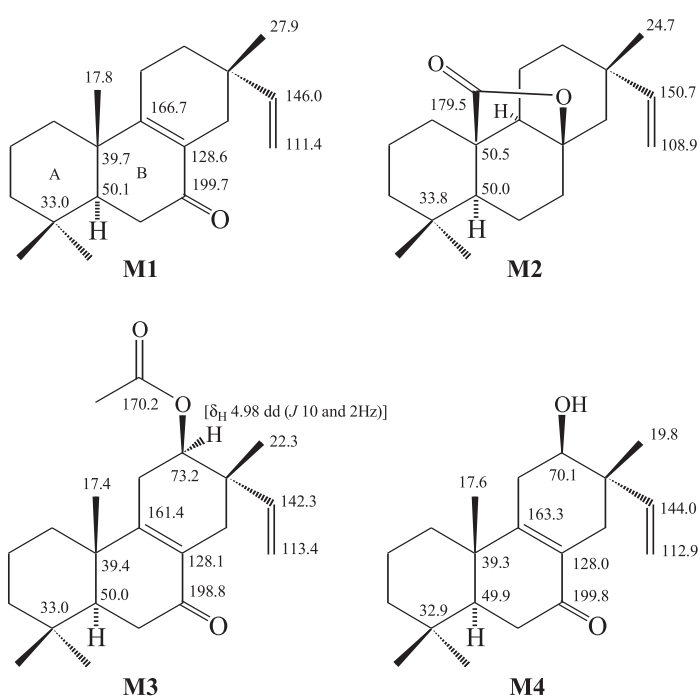

Figure 2. Model compounds used in the structure elucidation of compound 1 with some of their ${ }^{1} \mathrm{H}$ and ${ }^{13} \mathrm{C}$ NMR data. ${ }^{2,6,7}$ 
established and it was identified as the new isopimarane diterpenoid 8(9),15-isopimarandien-7-one-20,12carbolactone (Figure 1).

\section{Experimental}

\section{General procedures}

Melting point was determined on Kofler hot-stage apparatus and is uncorrected. The NMR spectra $(\delta$ ppm and $J$ in $\mathrm{Hz}$ ) were recorded on a Bruker DRX-300 spectrometer, in $\mathrm{CDCl}_{3}$ as solvent and as internal reference. LRCIMS and HRFABMS were obtained with a VG 7070E - HF spectrometer. FTIR spectrum with a $\mathrm{KBr}$ disc was recorded on a Nicolet Magna-IR 760 spectrometer. The UV spectrum was obtained on Care-003 spectrometer using $\mathrm{MeOH}$ as solvent. The optical rotation $[\alpha]$ value was obtained on a Jasco DIP-370 Digital Polarimeter using $\mathrm{CHCl}_{3}$ as solvent. CC employed silica gel 60 (230-400 mesh). TLC analyses were performed by using precoated silica gel $60 \mathrm{~F}-254$ and detection was accomplished by UV $254 \mathrm{~nm}$ irradiation. The HRCG-MS data were obtained on a HP CG5890 MS 5970 IEE $(70 \mathrm{eV})$ in the following conditions: Column SE-54 $50 \mathrm{~m}$, program: $\mathrm{T}_{\mathrm{i}}=140{ }^{\circ} \mathrm{C}, 8^{\circ} \mathrm{C} \mathrm{min}^{-1}, \mathrm{~T}_{\mathrm{f}}=290{ }^{\circ} \mathrm{C}$ with isotherm to $290{ }^{\circ} \mathrm{C}$ during $30 \mathrm{~min}$.

\section{Plant material}

Vellozia pusilla Pohl was collected at the National Park of Serra do Cipó, Minas Gerais, Brazil in 1993. Identification of the plant material was performed by Dr. Nanuza L. Menezes. A voucher specimen is deposited at the Departamento de Botânica of the Universidade de São Paulo, São Paulo, Brazil, by the number 298.

\section{Extraction and isolation}

The dried and powdered whole plant of Vellozia pusilla Pohl (1.2 Kg) was successively extracted with hexane, EtOAc and $\mathrm{MeOH}$ at room temperature. The solvents were removed under vacuum to yield hexane (38.7g), EtOAc (22.5g) and $\mathrm{MeOH}(14.8 \mathrm{~g})$ extracts. A portion of the hexane extract $(2.0 \mathrm{~g})$ was submitted to a silica gel $\mathrm{CC}$ eluted with a gradient of hexane in EtOAc obtained as described by Pinto et al. ${ }^{4}$ The TLC of the fraction eluted with hexane/EtOAc (9:1) showed 1 as a major compound. Colorless crystals (15.8mg) were obtained by recrystallizations from hexane/EtOAc (4:1).

\section{8(9),15-isopimarandien-7-one-20,12-carbolactone (1)}

Colorless crystals, mp $148-150^{\circ} \mathrm{C} ;[\alpha]_{\mathrm{D}}^{25}+41.7^{\circ}(c 1.0$,
$\left.\mathrm{CHCl}_{3}\right) ; \mathrm{UV} \lambda_{\max } / \mathrm{nm} 254(\mathrm{MeOH})\left(\varepsilon / \mathrm{dm}^{3} \mathrm{~mol}^{-1} \mathrm{~cm}^{-1} 19.9 \mathrm{x}\right.$ $\left.10^{3}\right)$; IR $v_{\max } / \mathrm{cm}^{-1} 1771,1683,975$ and 933 (KBr); LREIMS $\mathrm{m} / \mathrm{z}$ (\% rel. int.): $\mathrm{M}^{+}$not detected; 286 (2); 270 (25); 159 (40); 145 (35) and 91 (75); LRCIMS $m / z[\mathrm{M}+1]^{+} 315$; HRFABMS $m / z[\mathrm{M}+1]^{+} 315.1969\left(\mathrm{C}_{20} \mathrm{H}_{27} \mathrm{O}_{3}\right.$ requires 315.1960); ${ }^{1} \mathrm{H}$ NMR $,{ }^{13} \mathrm{C} \mathrm{NMR},{ }^{1} \mathrm{H}-{ }^{1} \mathrm{H}$ COSY, ${ }^{1} \mathrm{H}-{ }^{13} \mathrm{C}$ HMQC and ${ }^{1} \mathrm{H}-{ }^{13} \mathrm{C} \mathrm{HMBC}\left(300 \mathrm{MHz}, \mathrm{CDCl}_{3}\right.$, solvent as internal standard) (Table 1).

\section{Acknowledgements}

The authors thank Dr. David G. I. Kingston, Dr. A. A. Leslie Gunatilaka and the University of Nebraska, Lincoln for the HRFABMS. Also thank Dr. Carlos R. Kaiser from the NMR Lab. of the Instituto de Química - Universidade Federal do Rio de Janeiro for the NMR spectra and the Analytical Lab. of Far-Manguinhos - Fundação Oswaldo Cruz - RJ. Ana L. A. Dantas thanks CNPq (Conselho Nacional de Desenvolvimento Científico e Tecnológico) for fellowship support.

\section{REFERENCES}

1. Menezes, N. L.; Cienc. Cult. 1971, 23, 421.

2. Pinto, A. C.; Valente, L. M. M.; Silva, R. S., Garcez; W. S.; Queiroz, P. P. S.; An. Acad. Bras. Cienc. 1981, 53, 73.

3. Pinto, A. C.; Valente, L. M. M.; Silva, R. S.; Patitucci, M. L.; Gonzaga, L.; J. Chem. Res. (S) 1983, 104 and J. Chem. Res. (M) 1983, 841 .

4. Pinto, A. C.; Valente, L. M. M.; Silva, R. S.; Phytochemistry 1988, 27, 3913.

5. Valente, L. M. M.; Novis, A. O. B.; Lemos, M. G. J.; Dantas, A. L. A.; Silva, M. J. R.; Patitucci, M. L.; Pinto, A. C.; Derossi, A. P.; Oliveira, A. A.; BaJ, N.; Gunatilaka, L. A.; Kingston, D. G. I.; Menezes, N. L.; Abstracts of the $18^{a}$ Reunião Anual da Sociedade Brasileira de Química, Caxambu, Brazil, 1995.

6. Garcez, W. S.; Pereira, A. L.; Queiroz, P. P. S.; Silva, R. S.; Valente, L. M. M.; Peixoto, E. M.; Pinto, A. C.; Quim. Nova 1981, 4, 116; Pinto, A. C.; Garcez, R. S.; Silva, R. S.; Valente, L. M. M.; Peixoto, E. M.; Queiroz, P. P. S.; Pereira, A., L.; J. Chem. Res. (S) 1982, 154 and J. Chem. Res. (M) 1982, 1701.

7. Pinto, A. C.; Queiroz, P. P. S.; Garcez, W. S.; J. Braz. Chem. Soc. 1991, 2, 25.

8. Buckwalter, B. L.; Burfitt, I. R.; Felkin, H.; Joly-Goudket, M.; Naemura, K.; Salomon, M. F.; Wenkert, E.; Wovkulich, P. M.; J. Am. Chem. Soc. 1978, 100, 6445

9. Pinto, A. C.; Patitucci, M. L.; Silva, R. S.; Queiroz, P. P. S.; Kelecon, A.; Tetrahedron 1983, 39, 3351. 